2016-06-01

\title{
Partition, postal services and Ulster unionist politics 192127
}

Fitzpatrick, Claire

http://hdl.handle.net/10026.1/6730

10.1080/20514530.2016.1182388

International Journal of Regional and Local History

Taylor \& Francis

All content in PEARL is protected by copyright law. Author manuscripts are made available in accordance with publisher policies. Please cite only the published version using the details provided on the item record or document. In the absence of an open licence (e.g. Creative Commons), permissions for further reuse of content should be sought from the publisher or author. 
This is an accepted manuscript of an article published by Taylor and Francis, in

International Journal of Regional and Local History, 1 June 2016

DOI 10. 1080/20514530.2016.1182388

Acceptance date: 16 Feb 2016

\author{
'Partition, postal services and Ulster unionist politics 1921-27' \\ Dr. Claire Fitzpatrick \\ University of Plymouth \\ claire.fitzpatrick@plymouth.ac.uk
}

\begin{abstract}
This article examines the origins and development of the notion of an 'all-red' mail route policy in Northern Ireland in the years 1921-27 and what it reveals about the fractious nature of Ulster Unionism, its attitude to partition, and the construction of a separate Ulster identity. It explores the effects of partition on the notions of space and identity in Ireland, as well as how it affected the notion of a state under siege. Drawing on the largely untapped material in the British Postal Museum Archives, cabinet papers, parliamentary debates and local and national newspapers, it aims to contribute to current historiography of Northern Ireland and Ulster unionism in the 1920 s by looking at the ways local and sectional interests affected official policy, its attitudes to the Irish Free State and partition, and the more tangential debate concerning both
\end{abstract}


unionist and nationalist perceptions of Northern Ireland's identity. Finally, it examines the role of post and communications in and its relation to state building in Ireland during this transitional period which has hitherto largely been ignored in Irish history.

Key words: Ulster unionism; national identity; post and communications; post-partition Ireland.

At the annual dinner of the Belfast Chamber of Trade on 26 January 1927 Sir James Craig, Prime Minister of Northern Ireland, announced plans to establish an 'all-red' mail route for Ulster to make the postal system more efficient for business. ${ }^{1}$ This notion of a red route, which drew on the name given to Imperial mail routes served to underline the fact that Northern Ireland remained very much part of that Empire, had been discussed as early as 1922 and referred to the abandonment of the most common and arguably more economic route of Holyhead to Dún Laoghaire (formerly Kingstown) in the Irish Free State to Belfast in the north, in favour of the less successful Stranraer to Larne route. The idea to use this route to emphasise their 'otherness' to the rest of Ireland was not new to Ulster Unionists. After 1886, in opposition to Home Rule, Unionist leaders chose

${ }^{1}$ The Northern Whig and Belfast Post (Northern Whig), Jan. 271927. 
to travel to London via this route ${ }^{2}$ and since the partition of Ireland in 1920 the idea of abandoning the use of the Holyhead-Kingstown route in favour of the other routes came into focus and was the source of much debate, with various efforts made to implement it. Barely two months after Craig's speech, faced with increasing opposition from various sectors of society, notably the business community, who were old stalwarts of the Unionist regime, Craig announced the return to the Holyhead-Kingstown route. ${ }^{3}$

Craig's speech in 1927 was the official expression of an idea that had failed to take off. This article examines the origins and development of the notion the 'all-red' mail route policy, the reading of which reveals much about the fractious nature of Ulster Unionism during this critical period in the formation and consolidation of the state in Northern Ireland, and its attitude to partition and the construction of a separate Ulster identity. ${ }^{4}$ It explores the effects of partition on the notions of space and identity in Ireland, as well as how it affected the notion of a

\footnotetext{
2 J. Loughlin, 'Creating 'a Social and Geographical Fact': Regional Identity and the Ulster Question 1880s-1920s', Past and Present, May 2007, 162.

3 Although changed to Dún Laoghaire in 1922 by the Irish Free State government, Kingstown is used in this article as it was the name most used by the government of Northern Ireland, postal authorities and Northern Irish press.

${ }^{4}$ See P. Gibbon, The Origins of Ulster Unionism: the Formation of Popular Politics and Ideology in Nineteenth Century Ireland (Manchester, 1975); A. Jackson, The Ulster Party: Irish Unionists in the House of Commons 1886-1911 (1989); J. Loughlin, Ulster Unionism and British National Identity Since 1885 (1996); I. McBride. 'Ulster and the British Problem' in R. English and G. Walker (eds) Unionism in Modern Ireland (London, 1996) 1-18; D. Miller, Queens' Rebels (Dublin, 2007).
} 
state under siege. Drawing on the largely untapped material in the British Postal Museum Archives, cabinet papers, parliamentary debates and local and national newspapers, it aims to contribute to current historiography of Ulster unionism in the $1920 s^{5}$, by looking at the ways local and sectional interests affected official policy; its attitudes to the Irish Free State and partition, and the more tangential debate concerning both unionist and nationalist perceptions of Northern Ireland's identity. By examining the role of post and communications and its relation to state building in Ireland during this transitional period, an area which has hitherto largely been ignored in Irish history, ${ }^{6}$ it asks broader questions about Unionism, Nationalism and consolidating identities after partition.

\footnotetext{
${ }^{5}$ P. Buckland, The Factory of Grievances: Devolved Government in Northern Ireland 1921-39 (Dublin, 1979); B. Follis, A State Under Siege: The Establishment of Northern Ireland,1920-25 (Oxford, 1995); G. Walker, A History of the Ulster Unionist Party: Protest, pragmatism and pessimism (Manchester, 2004) chapter 2; P. Bew, P. Gibbon and H. Patterson, Northern Ireland 1921-2001 (London, 2002) chs 1 and 2; C. Reid, 'Protestant Challenges to the Protestant State: Ulster Unionism and Independent Unionism in Northern Ireland, 1921-39', Twentieth Century British History, 9, no. 4, (2008) 419-455.

${ }^{6}$ The main work which deals with the post in this period is C. Dulin, Ireland's Transition: The Postal History of the Transitional Period (Dublin, 1991); M. Reynolds, A History of the Irish Post Office (1993). The role of the GPO and the 1916 Rising is covered by K. Jeffery, The GPO and the Easter Rising; S. Ferguson, Self Respect and a Little Extra Leave: GPO Staff and the Easter Rising (Dublin, 2011); Both A. Jackson, The Two Unions, P. Joyce The State of Freedom: A Social History of the British State since 1800 (Cambridge, 2013) touch on the Post Office during the Victorian period.
} 
One of the themes explored by Oliver MacDonagh in his study of the AngloIrish conflict, States of Mind, is the role that concepts of territoriality have had in determining issues in Ireland's history:

Once painted a different colour on the map Northern Ireland became a pictorial entity in men's minds, with fresh claims and counter-claims about territoriality.... Place, in the political sense at least, had been permanently refocused. Yet the Treaty of 1922 had rendered the northern Unionist view of place, more instead of less ambivalent ... As things were...neither the Irish nor the British view of insularity or 'islandness' could be consistently embraced; and this geographical insecurity or unease has doubtless increased as the political separation of Northern Ireland from both the remainder of the United Kingdom and the Irish Republic becomes less 'unthinkable'.7

To some extent the story of an all-red mail route for Northern Ireland is a story of geographical uncertainty, of the refocusing of place. Furthermore, it is of defining and in some respects, imagining that place. The imagined communities by which Benedict Anderson described nations ${ }^{8}$ can be seen here. Historians have drawn on political geographers' notion of map images importance in the symbolisation of national identity and show how in post partition Ireland, Irish

${ }^{7}$ O. MacDonagh, States of Mind (London, 1983) 26.

${ }^{8}$ B. Anderson, Imagined Communities, (London, 2006) 
nationalists' map image was still one of the whole island as a distinct geographical entity. ${ }^{9}$ Partition was an unnatural state and remained unimaginable. The Irish Republican leader Éamon de Valera once declared that '[t]his Ulster is a thing of the mind only, non-existent in the world of reality ${ }^{\prime}{ }^{10}$ In 1920 the task fell to James Craig and Ulster Unionism to make that image a reality. With that came the careful construction and imagining of a sense of place, and the border and its protection in a physical and spiritual sense were integral to this. The border has been seen as a 'cultural divide,'11 a fundamental feature of the political landscape, which became a 'critical political instrument'. ${ }^{12}$ And just as 'the centrality of geography and landscape was key to nationalists' view of identity', Ulster Unionists argued the justification for partition was evidenced in the landscape. ${ }^{13}$ Loughlin argues that after partition Ulster Unionists faced the problem of trying to maintain exclusion by cultivating an image which convinced Britain 'it was a natural part of the national territory'. ${ }^{14}$

\footnotetext{
${ }^{9}$ J. Bowman, De Valera and the Ulster Question 1917-72 (Oxford,1982) Part 1 draws on an extensive discussion of the theories of political geography; C. O'Halloran, Partition and the Limits of Irish Nationalism, (Dublin 1988).

${ }^{10}$ Quoted in Bowman, De Valera and the Ulster Question 8.

${ }^{11}$ M. Heslinga, The Irish Border as a Cultural Divide', (Netherlands, 1979)

${ }^{12}$ M. Anderson, E. Bort (eds) The Irish Border (200) p.15.

${ }^{13}$ Loughlin, 'Creating 'a Social and Geographical Fact,' 164, 182.

${ }^{14}$ J. Loughlin, 'Consolidating “Ulster": Regime, Propaganda and Architecture in the Interwar Period' National Identities 1:2 1999162
} 
Much has been written about the way unionists constructed a distinct identity. ${ }^{15}$ While it has been suggested that the unionists were insufficiently imbued with ethno-national sentiment, drawing more on their sense of Britishness ${ }^{16}$, others have argued that Ulster unionists were indeed conscious of themselves as a nation and were preoccupied with fundamentally local issues. ${ }^{17}$ This distinctive Ulster Identity was a cultural project to serve political ends ${ }^{18}$. To J.C. Beckett, the use of the term 'Ulster' for Northern Ireland gave the new state a kind of continuity with the past as well as representing a well-recognised and established geographical division. As such Ulster had an embryonic nationalism, 'a state of mind' out of which emerged in particular circumstances a sense of 'national' distinctiveness. ${ }^{19}$ The quest for an all-red route and the reactions it elicited from both unionists and nationalists can be seen as both an affirmation and a rebuttal of that sense of national distinctiveness. Attempting to establish an all-red mail route was critical if Unionists were to consolidate this geographical distinction from the south and connection to Britain that was fundamental to their sense of identity.

\footnotetext{
${ }^{15}$ Loughlin, 'Consolidating Ulster'; G. McIntosh, The Force of Culture: Unionist Identities in Twentieth Century Ireland, (Cork 1999) explores the different ways the Northern Ireland state constructed its identity.

${ }^{16}$ Loughlin, 'Creating 'a Social and Geographical Fact,' 194

${ }^{17}$ A. Jackson cited in G. Walker, A History of the Ulster Unionist Party: Protest, Pragmatism and Pessimism 5.

${ }^{18}$ D. Officer and G. Walker, 'Protestant Ulster: Ethno-history, Memory and Contemporary prospects' National Identities, 2:3 2000, 294

${ }^{19}$ J.C. Beckett, 'Northern Ireland,' Journal of Contemporary History, 6 (1971): 121-34 at 130-1.
} 
Unionist historiography, which has emphasised the idea that the new state was under siege from both a hostile south and a largely unsympathetic and untrustworthy British government, has contributed to the development of the imaginings of Ulster as a place apart. Unionists, it has been argued by one sympathetic historian, were fearful that the 'newly acquired structures of selfgovernment would be sacrificed to facilitate an overall settlement' and so they withdrew behind their 'psychological ramparts' ${ }^{20}$ Furthermore, during this period Ulster unionists were also fearful of disunity within their ranks. Historians have argued that the unionist bloc was not united but becoming somewhat polarised. ${ }^{21}$ More recently it has been argued that the most significant political division in the inter-war years was an intra-unionist one. ${ }^{22}$ Looking at Ulster Unionism through the lens of the post office sheds new light on these divisions and how local and sectional, namely business, interests affected this.

\section{II}

\footnotetext{
${ }^{20}$ Follis, A State Under Siege, 188-9.

${ }^{21}$ G. Walker, A History of the Ulster Unionist Party: Protest, Pragmatism and Pessimism (Manchester, 2004) P. Bew, P. Gibbon and H. Patterson, Northern Ireland 1921-2001 Political Forces and Social Classes.

${ }^{22}$ C. Reid, 'Protestant Challenges to the Protestant State', 420.
} 
The Government of Ireland Act of 1920 partitioned Ireland into two political and geographical entities, the twenty-six county Southern Ireland and a six county Northern Ireland. At the time of the Act, the British were engaged in a war against republican forces, and so Northern Ireland remained to some extent, at least at the beginning of 1921, in constitutional limbo. However even before the May 1921 elections which saw Ulster unionists winning 40 of the 52 seats in the new Northern Ireland parliament, administrative structures were being put into place. When a truce was declared between Sinn Féin and the British government in July 1921, the task of transferring powers to Northern Ireland took second place to the desire of the British to reach an agreement with the south. Thus Northern Ireland was vulnerable from the outset. This delay also increased the pressure on Craig from the unionist grassroots opinion which has been described by one historian as 'restless and querulous'. ${ }^{23}$

As well as this uncertainty over the administrative structure of the new state there was an underlying anxiety about the geographical viability of the new territory. In November 1921 Lloyd George refused James Craig's call for dominion status on the grounds that the frontiers of the northern entity were

\footnotetext{
${ }^{23}$ Walker, A History of the Ulster Unionist Party, 59.
} 
based neither on natural features nor geographical considerations. ${ }^{24}$ This was to prove problematic in attempts by Ulster unionists to establish, consolidate and defend their state and what it represented. Thus, gaining control over the post and communications was important for establishing Northern Ireland as distinct from the rest of Ireland while confirming its membership of the United Kingdom. Postal services signified cohesion of the state, a common linking of peoples. The state's intrusion into the Irish landscape during the Victorian period as noted by Alvin Jackson is exemplified by the Post Office ${ }^{25}$ After partition, both states sought to use the Post Office to promote national identity. Michael Bilig refers to the 'ideological means' by which the nation is reproduced, as 'banal nationalism'. ${ }^{26}$ The unwaved flag, for example, acts as a constant reminder of the nation. Nationalism he argues contains a 'strong psychological dimension' and is not confined to national borders. ${ }^{27}$ The Irish Free State engaged in 'banal nationalism' by issuing postal stamps featuring an undivided map of Ireland and painting its post boxes green. The Irish Post box has been described as a 'silent servant and symbol of the state ${ }^{28}$. The postal service was described by the Belfast newspaper The Northern Whig as 'the life-blood of commerce and nervous system of the

\footnotetext{
${ }^{24}$ Loughlin, 'Creating a Social and Geographical Fact', 195.

${ }^{25}$ A. Jackson, The Two Unions, 207-8.

${ }^{26}$ M. Bilig, Banal Nationalism, (London, 1995) 6-8.

${ }^{27}$ Bilig, Banal Nationalism, 9.

${ }^{28}$ S. Ferguson, The Irish Post Box, (Dublin 2009).
} 
community' ${ }^{29}$ For the new governments both north and south control of the post represented control over their geography and image. Like Bilig's flag which hangs outside a public building, the post box and the postage stamp are reminders of nationhood. Craig's bid for an all-red mail route would also serve to remind the people of Northern Ireland of their distinct identity in opposition to that of the rest of Ireland, as well as flag its connection to Britain.

Gaining control over the post was to be a contentious process. Under the act of 1920 and subsequent Anglo-Irish Treaty of 1921, which allowed Northern Ireland to opt out of a Free State government, the Post Office in the six counties remained a reserved service, controlled by Westminster. Because the Imperial government's ultimate goal was to achieve Irish unity certain powers such as the Post Office were to be reserved until they could be transferred to an all-Ireland assembly. ${ }^{30}$ This caused great consternation to many within the new province and stimulated debate about the nature, power and authority of the regional government. The new Northern government's power was restricted in that it could not legislate on any postal matters. Furthermore, Westminster deducted the cost of reserved services from the reserved taxation. In other words, the Northern Ireland taxpayer paid for the Post Office even though its government did not

${ }^{29}$ Northern Whig, 2 November 1926.

${ }^{30}$ Buckland, The Factory of Grievances 3. 
control it. This was an example of one of the fundamental weaknesses inherent in the constitutional arrangements of 1920 and left the question of reunification open. In the south, it was felt that the Treaty stipulated that the Post Office was to be handed over to the Provisional Government for the area of Southern Ireland but did not give the Northern government any power over it and for a time it was wondered whether the Provisional Government would gain control of this. Indeed, in 1924 when there was talk of the possible control of postal services being given to Northern Ireland, the Irish Postmaster-General J.J. Walsh protested on the grounds that it weakened their claim to eventual reunification. ${ }^{31}$ In light of this, the Northern government had indicated it wanted the partition of all departments even before the Free State was established as it had little confidence in Britain's commitment to the establishment of a separate government. ${ }^{32}$

Unionists' fear of being abandoned by Britain intensified during British negotiations with Sinn Féin and led them to transfer as much power as possible from London to Belfast ${ }^{33}$. Ernest Clark, Under Secretary of Northern Ireland, was not only supportive of Craig's desire to build up a strong independent civil service in Belfast but has been described as the man who made possible the 'swift and

\footnotetext{
${ }^{31}$ M. Laffan, The Partition of Ireland, 111. Dept. of Taioseach.S 4174 National Archives Ireland (NAI)

${ }^{32}$ M. Maguire The Civil Service and the Revolution in Ireland, (Manchester, 2008) 133.

${ }^{33}$ M. Laffan, Partition of Ireland, 111.
} 
efficient formation of Northern Ireland' ${ }^{34}$ Relations between Clark and Craig, and John Anderson, Under Secretary of the Irish Office, and Dublin Castle officials, have been described as 'fraught.' ${ }^{35}$ In March 1921 well before the May elections which established Unionist rule, Clark had advised British departments that when Unionist rule was established in Northern Ireland, it would aim to get control over administration of the Post Office and other services which had been reserved. ${ }^{36}$ Craig and Clark remained suspicious of Dublin which they thought was being obstructive, preventing the smooth working of the Belfast administration. It is true that Anderson had been sceptical of the 1920 act and had tried to point out the shortcomings of 'the likely character of the six county state ${ }^{\prime 37}$ but he was also instrumental in facilitating the establishment of the administrative part of the new state..$^{38}$

After partition, the transfer of the postal service of the 26 southern counties provided the north with an opportunity to establish a more efficient postal service. ${ }^{39}$ A proposal in July 1921 called for the reorganisation of the Post office

\footnotetext{
${ }^{34}$ Follis, A State Under Siege, 6.

${ }^{35}$ Both Maguire, and Follis claim this; J. McColgan British Policy and the Irish Administration, (London, 1983).

${ }_{36}$ McColgan, British Policy and the Irish Administration, 56.

37 Ibid.

${ }^{38}$ E. O'Halpin, The Decline of the Union: British Government in Ireland 1892-1920 (Dublin, 1987) 211

${ }^{39}$ Letter from James Craig to F.G Kellaway PMG , 9 January. 1922, CAB 9F/44/2 Public Record Office Northern Ireland (PRONI)
} 
with Belfast as its central administration. Writing to Sir Evelyn Murray, the Postmaster-General for the United Kingdom, Anderson, claimed that there was 'a great deal to be said for this [suggestion] ...so long as Southern Ireland remains in a disturbed condition. On the other hand there is a great deal against it from the point of view of an All-Ireland sentiment'.$^{40}$ Clark stressed unequivocally that in the case of the Reserved services, the Northern Ireland government wished to be a self-contained unit, independent of Dublin control. ${ }^{41}$ This however was considered to be a costly and administratively difficult process and one which Murray argued would 'be extremely inconvenient and impractical', claiming sentimental considerations should not outweigh practical, financial and administrational objections to the proposal. ${ }^{42}$

III

Until April 1922 the whole of Ireland was served by the Kingstown to Holyhead mail service. Complaints about the mail service appeared in the press in Northern Ireland as early as 1919 and in February 1922 the practicality of diverting the mail to and from Northern Ireland from the Holyhead/Kingstown

\footnotetext{
${ }^{40}$ Letter 8 July 1921, Post 33/243 British Postal Museum Archive (BPMA)

${ }^{41}$ Copy of minute 1 July 1921 Post 33/243 BPMA

${ }^{42}$ Memo (nd) from Murray to Anderson Post 33/243 BPMA
} 
route to Stranraer/Larne was mooted by the Northern Ireland administration..$^{43} \mathrm{~A}$ number of factors prompted this. The situation in Ireland raised concerns about the efficiency of the route and security of the mail. The Belfast Chamber of Commerce (BCC) had expressed concern about the postal situation to the Postmaster-General as early as 1919 and in 1921 called for an inquiry into the 'serious inefficiency' of the route. The Mail train left Euston at $8.50 \mathrm{pm}$ and arrived at Kingstown at 5.50am but was not delivered to Belfast until after midday as it was held up in Dublin for two hours. Calls were made for an accelerated train service from Dublin to Belfast so that mail arrived by $9 \mathrm{am} .{ }^{44}$

The imposing of a boycott of Belfast goods by the southern government in 1920 and IRA activity on the border exacerbated concerns about the service. The boycott which aimed to unsettle the northern economy was 'at this stage directed towards partition'.$^{45}$ Mail trains were often targeted. ${ }^{46}$ The train from Belfast to Dublin was often interfered with at Drogheda and mail taken, with one report claiming that trains carrying the northern mails for Dublin and the south were

\footnotetext{
${ }^{43}$ Miscellaneous COM 21/1 PRONI.

${ }^{44}$ Belfast Chamber of Commerce (BCC) minutes 17 Nov 1917 p.162; 17 Jan 1921 176.D 1857/1/AB/8 PRONI.

${ }^{45}$ D.S Johnson, 'The Belfast Boycott, 1920-22' in J.M. Goldstrum, L.A. Clarkson (eds.), Irish Population, Economy and Society (Oxford, 1981) 287.

${ }^{46}$ Letter 27 Mar. 1922. Post 33/343, BPMA; Witness Statement 0657, P. Marron, Bureau of Military History, NAI.
} 
attacked and mail was stolen five times in two weeks. ${ }^{47}$ This "very considerable interference ${ }^{\prime 48}$ had heightened fears about security of the fledgling state. ${ }^{49}$ The unsettled conditions in the south added to this concern. In January 1922 Craig wrote to the Post Office Secretary in Dublin, F.G. Kellaway, about the Postal service in Ireland being so 'honeycombed with intrigue, no Government department that was ready to entrust correspondence of a secret or confidential nature' through the Irish postal system. ${ }^{50}$ It was suggested that the Northern government would press for an alternative route..$^{51}$

The President of the BCC, an important stalwart of the unionist regime, instrumental in helping fight Home Rule, doubted that the Dublin Post Office could be trusted when handling the mail destined for the six counties. ${ }^{52}$ The BCC had been closely involved in the talks which produced the Government of Ireland Act and had embarked on a campaign to get businessmen elected to the new Northern Ireland parliament. ${ }^{33}$ Indeed John Milne Barbour who became Minister of Commerce in 1925 had been President of the BCC in 1911. By March 1922 due to

\footnotetext{
${ }^{47}$ wire sent by Mr Baird of the Belfast Telegraph to PMG London 3 Apr. 1922. COM/21/3, PRONI.

${ }^{48}$ Draft Memorandum 27 Apr. 1922.COM/ 21/1, PRONI.

${ }^{49}$ Letter 27 Mar. 1922. Post 33/343, BPMA.

${ }^{50}$ Letter 9 Jan. 1922. CAB 9F/44/2, PRONI.

${ }^{51}$ Memo 7 Feb 1922 POST 33/243, BPMA

52 Letter 9 Feb. 1922 Post 33/243, BPMA.

${ }^{53} \mathrm{P}$. Ollerenshaw, 'Businessmen and the Development of Ulster Unionism', The Journal of Imperial and Commonwealth History, 2000, 58.
} 
the 'considerable disorganisation and loss of mails to and from Northern Ireland' caused by the 'disturbed conditions' in the Irish Free State, plans were made to divert the mail routes. ${ }^{54}$

The decision to look for a suitable alternative mail route would affect the business sector in Northern Ireland and expose tensions within the Unionist community. A minute for the Ministry of Home Affairs argued that the political arguments in favour of the principle of sending mails via Larne were strong but cautioned against making it public as political capital might be made of the 'grave disadvantage' that some towns in the north would suffer if the proposal was adopted. ${ }^{55}$ An Advisory Council to the Ministry of Commerce minute claimed that any further delay in mails would affect commercial interests and that 'it might on the whole be preferable to take the risk of transit through Southern Ireland rather than incur this delay', but the ministry did not share this view. ${ }^{56}$

In July 1922 Cecil Litchfield, secretary to the Minister of Commerce, wrote to Wilfrid Spender, the first secretary to the Northern Ireland cabinet, suggesting that the government 'must give up any idea of using the Holyhead-Kingstown

\footnotetext{
${ }^{54}$ Memo, 22 March 1922, POST 33/243 BPMA; Miscellaneous. COM 21/1 PRONI.

${ }_{55}$ Ministry of Home Affairs minute sheet 28 Feb. 1922 COM/21/1,.PRONI,

${ }^{56}$ Minute 20 Mar 1922.. COM/21/1, PRONI,
} 
route', despite it being the 'only thoroughly organised and equipped mail service in Ireland'. His reasons were twofold: security and financial. Concerned that it 'would be years' before Northern Ireland could feel that mail would be safe on that route, he also anticipated that the new Irish Free State government would put claims on the government to cover the cost of carrying the mails through the Free State. ${ }^{57}$ With the situation in the south deteriorating, Spender asked Litchfield if any letters with an official stamp were passing through the Irish Free State. ${ }^{58} \mathrm{~A}$ cabinet minute on 24 June 1922 claimed that the Irish Free State could hold up mails for Northern Ireland as they desired ${ }^{59}$. The idea of an 'all-red' route for the whole of Northern Ireland was then discussed by the GPO in London in August $1922^{60}$. By then the south was embroiled in an internecine conflict and in March 1923 a British postal circular gave instructions not to send mail destined to Northern Ireland via the Holyhead route. ${ }^{61}$ Discussions over potential mail routes reflected deeper divisions within Unionism and the wider community, and underlined insecurities amongst stakeholders in the newly established state.

The accessing of a more suitable route which might need improvements, and control over the Post Office, raised the issue of cost. Correspondence between

\footnotetext{
${ }^{57}$ Letter 6 July 1922., CAB 9F/44/2, PRONI

${ }^{58}$ Letter 3. Aug. 1922. COM 21/1, PRONI,

${ }^{59}$ Minute, 24 June 1922., HA 5/1487 PRONI.

${ }^{60}$ Letter 3 Aug. 1922, COM 21/1 PRONI

${ }^{61}$ British Postal Circular No 266814 Mar 1923.BPMA,
} 
Litchfield and Spender acting for Craig is interesting for what it reveals about the relationship between the Northern Ireland administration and the British government. There were concerns about the question of control over the Post Office and the financial implications of this. Spender had suggested that Craig would like Litchfield to try and get as much control over the postal service but without any of the financial burden. ${ }^{62}$ It was hoped that the British Government would bear the cost of establishing new arrangements for this. As Litchfield wrote to Spender:

Great Britain herself is interested in having an efficient mail service direct to Ulster, and it seems only right that she should bear the cost of the improvements, partly for that reason and partly because the British government, by their own action in creating the Free State territory have deprived us of the only efficient mail service for Ireland.

It was, according to Litchfield, their responsibility to provide an alternative. ${ }^{63}$ Although there were auxiliary routes this did not, in Litchfield's view, 'diminish the moral responsibility of the Imperial Government' to rectify the situation. This is yet another instance of the complex relationship between the Northern Ireland and Imperial governments which saw Northern Ireland demanding a degree of autonomy, represented in an all-red mail route, but not wanting to pay for it.

62 Letter 10 July 1922 CAB 9F/44/2 PRONI,

${ }_{63}$ Letter 6 July 1922, CAB/ 9F/44/2. PRONI, 
The spectre of a Boundary Commission to settle the question of the Irish border, the provision of which had been made under Article 12 of the Anglo-Irish Treaty, also cast a shadow over the mails question. This was of deep concern to Unionists, who had not been party to the Treaty negotiations, and the threat it represented loomed over the province in the early years. The state mobilised against it and employed as much of what has been termed an 'ongoing historico-geographical dimension of Unionist propaganda' ${ }^{\prime 64}$ to build up a picture of an autonomous state. It has been argued that the more credibly the geographic, political and historical singularity of the new state could be established the greater the case for denying border revisions. ${ }^{65}$ An all-red mail route could indeed give weight to this. A letter from James Craig to the Postmaster-General Joynson-Hicks, who was also the minister responsible for Westminster-Northern Ireland relations, in May 1923 noted that the reason for the establishment of a separate postal system in the south was that the northern government needed to establish lines of communication between Northern Ireland and Great Britain which would lie altogether outside Free State territory. He saw it as matter of importance not just for Northern

\footnotetext{
${ }^{64}$ Loughlin, 'Creating 'a Social and Geographical Fact', 188

${ }^{65}$ Ibid, 190.
} 
Ireland but also to those in United Kingdom trading with Ulster. ${ }^{66}$ The attitude of the Free State government and the campaign by the anti-Treaty IRA induced the need for physical defence of the borders and contributed to the anxiety of many in the new state about its long term prospects. The creation in 1923 of a customs barrier around the Irish Free State and other policies which reflected a distinct and catholic identity alarmed some Unionists who saw it as evidence of the south's irredentist claims and contributed to desire to strengthen links with the empire. ${ }^{67}$ Craig and Clark's first concern was to secure the existence of the state and in doing so they also sought to build up a defensible frontier against the south, backed up by force. Unionist historiography has described this state-building period as a state under siege ${ }^{68}$ and this fear, uncertainty and 'siege mentality' must be considered when looking at the decision to seek a red route for Ulster.

And so alternative mail routes, secure from the uncertainties and perils of passing through the Irish Free State, such as Fleetwood in Lancashire, and Stranraer on the Scottish coast, which crossed to Larne on the Antrim coast, were promoted. At Westminster the Ulster Unionist MPs worked hard on the mails issue, trying to secure from the Postmaster General assurances that delivery of

\footnotetext{
${ }^{66}$ Letter $25^{\text {th }}$ May 1923,Post 33/243. BPMA

${ }^{67}$ M.J. Kennedy, Division and Consensus: The Politics of Cross Border Relations in Ireland 1925-1969, (Dublin, 2000) 25

${ }^{68}$ See Follis, A State Under Siege.
} 
mail to Northern Ireland should be via Larne or Belfast ${ }^{69}$ The Postmaster-General replied that as far as was possible all mail destined for Belfast and surrounding districts was being diverted from Holyhead-Kingstown. Serious delays were reported throughout 1925 particularly on the Stranraer-Larne service..$^{70}$ Pressure was mounting from some business circles in Belfast to revert to the old route. But in July 1925 the BCC recommended that both routes be improved rather than there be a reversion to the old route and referred the matter to the Postal Committee. ${ }^{71}$ There was some speculation that this was due to fears surrounding the Boundary question as the Commission was preparing its report. ${ }^{72}$ Later in a statement F.L. Heyn, Chairman and Convenor of the Postal and Telegraphs Standing Committee for the BCC, argued that while there was 'no question of a reversion of the principal mails to the Holyhead-Kingstown route' it would be used for 'residue mails' ${ }^{73} \mathrm{~A}$ reversion to the former route was not ideal for it 'appear[ed] to involve a contradiction of the principles underlying the recent "clean-cut" between the Northern Ireland and Free State postal services' ${ }^{74}$ It must be noted that while mails to Belfast and surrounds were not to be taken via Holyhead-Kingstown, mails to other parts of Northern Ireland were. This brings into question why a

\footnotetext{
${ }^{69}$ Written answers 13 March 1923 Parliamentary Debates Commons, series 5, vol 161, cols 1313-4.

${ }^{70} \mathrm{BCC}$ minutes D 1857/1/AB/8.PRONI.

${ }^{71}$ BCC Minutes 30 July 1925 262, D 1857/1/AB/8, PRONI.

72 The Irish News, 26 Aug 1925.

${ }^{73}$ BCC Minutes 5 Nov 1925 268, D 1857/1/AB/8 PRONI.

${ }^{74}$ Northern Whig, 2 November 1926, COM 21/44. PRONI
} 
unilateral all-red route was not adhered to and is indicative of the complex and multifaceted nature of Ulster Unionism and that not all within the Unionist community welcomed it.

The settling of the Boundary question in 1925, with no revisions made to the existing border, allayed unionist fears and there appeared a slight shift on the mail question although any talk of reversion was resisted in some quarters. The Unionist MP and editor of The Northern Whig, Robert Lynn, wrote to the Secretary of the GPO insisting that the Fleetwood route be improved as he did not see the advantage of the Holyhead route. In a note to the Secretary of the GPO, William Mitchell-Thomson, the new Postmaster-General, supposed 'it was possible that the heavy demands of the House of Commons' had hindered Lynn gaining personal experience of the gain to Belfast newspapers and to the public generally in Northern Ireland of this Holyhead route. ${ }^{75}$ Lynn's newspaper underlined this determination to keep the Larne-Stranraer route and proposed the acceleration of the service, which 'should commend itself to the hard-headed people of Northern

\footnotetext{
75 `Northern Ireland mail arrangements on the border', Letter, 5 Aug. 1927. Post 33/343, BPMA.
} 
Ireland. ${ }^{176}$ Through the editorial Lynn attacked the deficiencies of the constitutional structure which he felt left Northern Ireland in a weak, disadvantaged position. He wondered if 'the intensity of our loyalty to the British connection had stood in the way of an improvement'.77

The Belfast Telegraph noted that 'public memory is short, but the memory of the Ulster public is not so weak as to have forgotten why the route was dropped in favour of Larne-Stranraer'. It reminded its readers of the times trains were derailed and mails seized by armed raiders and asked what service had a finer record than Larne-Stranraer which 'served the Ulster capital well in times of national peril and of political crisis at home. ${ }^{\prime 78}$ In times of political tension it was found that it was most undesirable that Belfast's correspondence should be handled in Dublin.

The nationalist papers were critical of the move. An editorial of the Frontier Sentinel, based in Newry in Co. Down, but also serving Co. Armagh and Co. Louth, argued that it was 'extraordinary' that people were prepared to 'scrap a service' which has given 'every satisfaction and little fault ... In spite of genius

\footnotetext{
${ }^{76}$ Northern Whig, 2 Nov 1926.

77 Northern Whig, 2 November 1926.

${ }^{78}$ Belfast Telegraph, 10 September 1925.
} 
arguments to the contrary people cannot be got to believe that sixteen miles further distant really means sixteen miles nearer' ${ }^{79}$ The Belfast based Irish News, levelled the blame for the crisis in mails at the BCC calling for this 'autocratic body' to be put in its proper place. ${ }^{80}$ Interestingly, an editorial of the unionist Belfast News-Letter argued that reversion to the old route would be a step on the way to improving relations between the 'two governments and peoples' as the south would view it as 'a gesture of confidence and friendliness'. ${ }^{81}$

Businessmen attacked the proposal. The $14^{\text {th }}$ annual meeting of the Belfast and District Chamber of Trade in 1926 the declared that the Holyhead to Kingstown route was the most advantageous. The President William J. Hardy argued there was 'no sane reason' why the Chamber and other representative bodies should not use influence and revert to the Kingstown route. He believed that '[e]verybody in the North of Ireland would desire to cultivate better relations with their fellow-countrymen in the South' and thought that by bringing in their mails via Kingstown they would at any rate be extending a friendly gesture to the Free State...' It was felt that businessmen were suffering too much from the present system and that mails were too important 'to allow any political flavour to enter

\footnotetext{
${ }^{79}$ Frontier Sentinel, 2 April 1927.

${ }^{80}$ Irish News, 12 October 1926.

${ }^{81}$ Belfast News-Letter, 13 November 1926.
} 
into it'. ${ }^{82}$ Later a delegation from the BCT met with the Ministry of Commerce to urge a reversion. However the $\mathrm{BCC}^{\prime}$ s Postal Committee on the mails question reported back to the $\mathrm{BCC}$ that they were in favour of improving existing direct routes between England and Belfast and recommended to the Council to have the question reconsidered by the Government, Postal authorities and carrying companies. ${ }^{83}$

At a popular level there appeared to be much support for an all-red route from loyalists in the border towns. It has been argued that that local society was very influential in forming and consolidating nationhood and the territorial state. ${ }^{84}$ Described as 'by no means an easy or satisfying place to govern', with 'little scope for impartial government,' 85 Northern Ireland was highly localised and politicised with much interaction between the people and the government. Political interference was constant ${ }^{86}$ and 'ministers subjected to intense pressure on less momentous issues' ${ }^{87}$ and this is borne out somewhat by the correspondence received by Craig's office on all sorts of matters concerning the post. The government was inundated with letters from disgruntled and worried inhabitants

\footnotetext{
${ }^{82}$ Northern Whig, 29 October 1926.

83 Report of the Proceedings of the meeting of the Postal Committee on the Mails Question. $\mathrm{COM} / 21 / 44$, PRONI.

${ }^{84}$ P. Sahlins, Boundaries: The Making of France and Spain in the Pyrenees, 8.

${ }^{85}$ P. Buckland, James Craig (Dublin, 1980) 89-90.

${ }^{86}$ Bardon, A History of Ulster, 497.

${ }^{87}$ Buckland, James Craig, 93.
} 
of towns on the border ${ }^{88}$ Letters from residents in south Fermanagh supported the idea of a red route and protested emphatically against their letters and parcels being delivered by Free State authorities. ${ }^{89}$ One telling letter asked: 'what do the Belfast mandarines (sic) care about the letters of the people in the counties? Nothing. The 'true-blues of Tyrone and Fermanagh are only useful for voting purposes at election times. In the intervals they are deliberately ignored, when they are not forgotten' .90 It has been argued that in the confused and traumatic circumstances that marked the new state's beginnings only the Protestant community had 'a clear sense of direction'.$^{91}$ The fractious relationship between Unionism and the grassroots unionist community is again reflected here.

\section{VI}

By the end of 1926 there was some discussion to revert to the old route. In a memorandum in November, the Ministry of Commerce argued that as 'the strong disinclination of the Belfast and Co Antrim business community towards the Holyhead-Kingstown route had moderated in recent months' it welcomed at least the contemplation of a reversion to the old route. This was partly due to 'the

\footnotetext{
88 Various, HA 5/1487 PRONI

89 'Northern Ireland mail arrangements on the border' Post 33/1137 BPMA,

${ }^{90}$ Irish News, 12 September 1925.

${ }^{91}$ P. Buckland, 'A Protestant State' in D. George Boyce, Defenders of the Union: A survey of British and Irish unionism since 1801, (London, 2001) 212.
} 
prolonged absence of interference with the mails. ${ }^{92}$ In Portadown, the Chamber of Commerce protested against an all-red route of Ulster declaring that the perfectly obvious route is Holyhead - Kingstown. ${ }^{93}$ In Derry any attempt by 'red-routers' to have the English mails diverted to come via Stranraer-Larne failed as the businessmen of the Maiden city were not duped by specious promises'. ${ }^{94}$ An editorial in the Irish News ridiculed the idea of a red-route which it argued would delay mails in areas where it was to be enforced claiming it was 'grim in its frenzied folly' that 'loyal and patriotic All-Reddists of Armagh, Tyrone, Fermanagh, most of Down and all of Derry' insisted on getting their letters via an untainted route which resulted in a delay for all..$^{95}$

Nevertheless Craig continued his pursuit of an 'all-red' route continuing his discussions with the London, Midland and Scottish railway. ${ }^{96}$ He was backed by the Minister of Labour, John Andrews. ${ }^{97}$ In January, Craig embarked on one of his many tours of the province. These tours were first undertaken in 1922 to allay fears of unionists living in the border areas. On these tours, he would listen to local grievances and problems and, according to one his more critical biographers,

\footnotetext{
92 Memo November 1926, COM/21/44, PRONI,

93 Belfast News-Letter, 22 February 1927.

94 Northern Whig, 11 February 1927.

95 Irish News, 1 February 1929.

${ }^{96}$ Extract from Draft Conclusions of cabinet meeting 1 Dec 1926, COM/21/44,PRONI.

${ }^{97}$ Extract from Draft Conclusions of cabinet meeting, 18 Nov 1926, COM/21/44. PRONI
} 
show a responsiveness which came from not only his good nature but from 'an almost pathological fear of opposition within Northern Ireland' which led him to display 'an indecent degree of political timidity'.${ }^{98}$ He would dispense with government advice often without the approval of his fellow ministers. ${ }^{99}$ To one of his earlier hagiographers, the tour of 1927 was 'informal and friendly' and allowed Craig 'to hear from the people themselves what their troubles were, and to consult them about remedies' ${ }^{100}$ It was during this tour that he made his speech extolling the virtues of an all-red route while also visiting sites of places where new ports could be built to facilitate it. Maps were presented to Craig and he listened to plans about constructing a mail route which would avoid the Irish Free State. ${ }^{101}$ Perhaps buoyed by these plans Craig declared publicly his support for an all-red mail route for Ulster.

However at a cabinet meeting held on 1 March 1927, barely three weeks after his speech to the BCT, Craig concluded that he did not think "we" could continue to 'ignore the persistent representations from the Belfast business community', and that for the time being 'we should agree to the mails being allowed to go via Kingstown'. The Minister of Labour protested and expressed

\footnotetext{
98 Buckland, James Craig, (Dublin,1980) 105.

${ }^{99}$ Ibid, 103-4.

100 St. John Ervine, Craigavon: Ulsterman, (London, 1949) 513.

${ }^{101}$ Manchester Guardian, 17 February 1927.
} 
strong disapproval of 'our being dependent upon the Free State for our mail service' ${ }^{102}$

On 11 March 1927 the Ministry of Commerce confirmed that the Northern Ireland government had decided to revert to the use of the Kingstown route for mails to and from the whole of Northern Ireland except Larne and other areas in Co. Antrim better served by the Stranraer service. ${ }^{103}$ It was argued that the possibility of accelerating the Stranraer route now met with considerable practical difficulties and that the interests of Northern Ireland would best be served by the old route. Due to the interest the question had excited, the 'Ulster government are anxious that the change be carried out without any publicity' ${ }^{104}$ The Chamber of Trade congratulated Craig on restoring the mails. ${ }^{105}$ The Chairman of the Postal Committee claimed that while they all knew Craig had been working to establish an 'all-red-route', which they supported, they hoped this would not be carried out at the expense of business. ${ }^{106}$

Answering questions in the Northern Ireland House of Commons, Craig explained his actions claiming what he had adopted at the moment does not in

\footnotetext{
102 Extract from Draft Conclusions of cabinet meeting 1 Mar 1927, COM/21/44, PRONI.

${ }^{103}$ Memo, 11 Mar 1927, POST 33/243, BPMA.

104 Note dated 10 Mar 1927, POST 33/243, BPMA

105 Northern Whig, 5 April 1927.

106 Irish Times, 21 April 1927.
} 
any way interfere with the policy of the Government to go on and to persevere to get an All-Red Route'. He argued that it was a matter of 'economic expediency', made mostly in response to pressure from business circles and 'there was never any idea of going behind anybody's back' ${ }^{107}$

Joseph Devlin, leader of the minority Nationalist Party, congratulated the Minister of Commerce on bringing an end to the terrible inconvenience but asked when the House might be able to discuss the matter, knowing full well that, as the Post Office was a reserved service, it could not. Devlin used this to air grievances about the deficiencies of the constitutional arrangements in the north. He intended to raise 'as a matter of principle and right' this whole question, asking what 'precisely is the power of this House' in relation to reserved services and the 'right to discuss either legislative, administrative, or financial matters that affect this House' ${ }^{108}$

He raised the issue again on 28 March when he criticised the government for the initial decision to change the mail route five years before and the gravest inconvenience caused to the community that ensued, and questioned the real motive for changing it. Accusing the government of not being honest in their

\footnotetext{
${ }^{107}$ Joseph Devlin speech to House of Commons Northern Ireland 31 Mar. 1927 Parliamentary Debates Commons Northern Ireland (NI) series 1 vol. 7 col. 586.

${ }^{108}$ Joseph Devlin speech to House of Commons Northern Ireland 11 May 1932 Parliamentary Debates Commons NI series 1 vol. 14 col. 1339.
} 
reasons, he wondered whether it had been because of the inconvenience to commercial interests of the province and, if so, why had it not been reverted to years ago? Drawing on the government's explanation that mail was indeed being delivered at the moment to some places in Northern Ireland via that route, he accused the government of an 'arrant piece of hypocrisy':

'[W]hile you are making the public believe that you would have nothing to do with the Free State and would not allow letters to pass through the Free State, you were actually sending the letters for Lisburn, Lurgan and Portadown through Holyhead, and then standing up in Belfast and telling all your friends in Belfast "Oh, we will not touch the Free State with a forty-foot pole; we will not have our letters desecrated by the unholy hands of Free Staters being put on them."... [But] you were actually allowing all the mails to pass through all the most loyal portions of the North of Ireland. ${ }^{109}$

Devlin believed that 'all the sacrifice of the commercial interests' of the north was a result of the government pandering to the more extreme section of loyalist community. ${ }^{110}$ In this sense the debates over the post reflected broader issues about the nature of politics in the province, namely how politics was done and constitutional limitations of the new state.

\footnotetext{
109 Devlin, 28 March 1927, Parliamentary Debates Commons, NI, series 1, vol. 8, col.433.

${ }^{110} \mathrm{Ibid}, \mathrm{col} .434$.
} 
Elsewhere there was outrage at the fact that the Ulster Unionist MPs at Westminster had been humiliated by their government as they had not been informed of this change in policy directly. ${ }^{111}$ The southern newspaper the Irish Independent was critical of Craig's handling of the matter, his 'unfortunate method which he has adopted of doing the thoroughly sensible thing in reverting to the Holyhead-Dún Laoghaire route for the carriage of mails'. He had alienated many including his own brother Captain Charles Craig who, under the impression that the red route idea was still being contemplated, had continued to work with the London, Midland and Scottish railway on the policy of improving the other routes. ${ }^{112}$ Joseph Devlin had touched on this in parliament when he mockingly said he was 'sorry to see that there is a split in the Unionist camp' and asked: 'Is the policy of the Gentlemen representing us in the Imperial Parliament a different policy to the policy represented by the Government and hon. Gentlemen opposite?'113 James Craig defended his position and claimed a harmonious relationship existed between unionists at Westminster and Belfast. ${ }^{114}$ Later the Northern Ireland cabinet had to discuss the

\footnotetext{
111 Northern Whig, 25 March 1927.

112 Irish Independent, 29 Mar 1927.

113 Joseph Devlin, speech to House of Commons NI, 27 March 1927, Parliamentary Debates, Commons NI series 1 vol. 7 col. 434.

${ }^{114}$ James Craig, speech to House of Commons NI 31 Mar 1927,Parliamentary Debates, Commons NI series 1 vol. 8 col. 586 .
} 
need to improve communications between the Westminster MPs and the government in Northern Ireland. ${ }^{115}$

At Westminster an incredulous Robert Lynn continued to raise questions about the postal services between Great Britain and Northern Ireland and demanded to know how the Government intended to remedy the grievances? ${ }^{116}$ His newspaper the Northern Whig demanded to know what had caused Craig to change his opinion and abandon the policy. It argued that recent developments in the Irish Free State such as an ambush by Free State soldiers near Dublin, rather than being dismissed as the 'amusements of a few playboys of the Western world' should strengthen the case for the all-red route. ${ }^{117}$ Despairing of the government's decision, the editorial argued that the change was at variance with the attitude to which it had adhered since the inauguration of self-government and that it was opposed to the permanent interests of Ulster. Finally it reiterated its claim that the southern government could not be trusted: 'The spirit of disorder and virulent Anglophobia is still active in the south, and it is impossible to forsee what sinister form it may assume at any time.' It continued to argue for the red route at

\footnotetext{
115 Walker, A History of Ulster Unionism, 62.

116 Robert Lynn question to House of Commons ,24 March 1927, Parliamentary Debates, NI Commons series 5 vol. 204, cols. 565-6.

117 Northern Whig, 29 March 1927.
} 
whatever cost. ${ }^{118}$ It was deemed 'humiliating' if those who had 'defeated the sinister combination' which tried to force Northern Ireland 'under an alien yoke', had to 'admit their inability to give effect to the Prime Minister's clearly and definitely expressed conviction that, as Ulster is part of the United Kingdom, all mails dealing with our important matters' should only pass through Great Britain to Northern Ireland and vice versa.' ${ }^{\prime 19}$

Others objected 'both on the grounds of patriotism and business security'. ${ }^{120}$ The London Correspondent of the Belfast Evening Telegraph cautioned that there was no guarantee that disorder would not break out in the Free State as recently large parcels of newspapers from the Holyhead boat 'were burnt at Kingstown'. ${ }^{121}$ There was also some concern about any possible costs that having a mail route pass through the Free State might incur. A significant number of letters to the newspapers and to the Ministry of Commerce reveal this. A letter to the editor of The Northern Whig from 'Ulsterman' asked if the Free State was to receive a proportion of the postage for letters passing through their country ... Let us not forget that the Free State, in this matter (my italics) is a foreign country. ${ }^{122}$ Interestingly Sam Kyle, the Northern Ireland Labour Party MP, criticised Craig's

118 Northern Whig, 23 March 1927.

119 Northern Whig 24 March 1927.

${ }^{120}$ Letter to Ed., Northern Whig 26 March 1927

${ }^{121}$ Belfast Evening Telegraph 23 March 1927.

${ }_{122}$ Northern Whig, 23 March 1927. 
use of the term 'all-red' for it implied the Irish Free State was outside the empire, which it was not. He called for it to be called an All-British route. ${ }^{123}$

The decision to revert to the old route was welcomed by different sections of society. Some like Sir William Coates, a member of the Northern Ireland Senate, and a man described by the Irish Times as a "pillar of Unionism,'124 said that the commercial community was 'delighted with the arrangement ... as delays had caused incalculable loss of money'. ${ }^{125}$ Some saw it as a step towards more cordial relations between the two states. A letter to the newspaper from a 'wholesale merchant' wrote argued that as there was now a responsible government in the Irish Free State:

[T] here is no reason why the mail service should not go by this route. A little more come and go as between North and South would be to the mutual benefit of both governments. The best guarantee for peace along the border about which some of our Northern ministers would appear so gravely concerned is a freer interchange of commodities between North and South. [I] Hope it will be a forerunner of a closer understanding between north and south. ${ }^{126}$

\footnotetext{
${ }^{123}$ Sam Kyle, speech to House of Commons, NI, 31 March 1927, Parliamentary Debates Commons, NI, series 1 vol. 8. col. 585 .

124 Irish Times 2 April 1927.

125 Belfast News-Letter, 23 March 1927.

${ }^{126}$ Northern Whig 26 March 1927.
} 
This idea was reiterated in the Dublin press. The Dublin Evening News welcomed the decision for bringing the north in with the south in a common mail service and marking the northern government's acknowledgement of the settled conditions which now prevailed in the Free State. It was hoped it would be followed by the other actions to bring about closer and friendlier relations. ${ }^{127}$ Others were less conciliatory. The Irish Independent reported that the Belfast ministers have 'swallowed their pride and taken a course that prudence should long ago have dictated ... The Saorstat gains nothing by having the Northern mails pass across its border; but the commerce of the North does'. ${ }^{128}$ It was suggested that 'antagonism to the Free State' was the only reason for the 'nonsense' and the episode was seen as 'an example of the pettiness and squalor of the spirit and prejudice of the Ascendency in this city'. ${ }^{129}$

The Ministry of Commerce received letters of thanks from various county Chambers of Commerce while a letter from a Mr R. Stevenson and Sons expressed 'our pleasure at the return from insanity of certain people and the adoption of the Kingston (sic)- Holyhead route'. ${ }^{130}$ The BCC was singled out for criticism. It was claimed by some in nationalist circles that this 'chamber of political horrors' was

\footnotetext{
127 Dublin Evening News, 23 March 1927.

128 Irish Independent, 23 Mar 1927.

${ }^{129}$ Irish News, 2 Apr 1927.

${ }^{130}$ Letter 31 Mar 1927., COM 21/44 PRONI
} 
'the cause of it all' which, 'instead of safeguarding the interests of the commercial community it has only been an ante-chamber of the Unionist Party'. ${ }^{131}$

\section{VII}

In March 1927 during the public debate on the all-red route an editorial in the southern and traditionally unionist newspaper The Irish Times claimed:

A common mail service is a very small link in the chains of Irish unity; but every little helps. Since the establishment of separate governments in Dublin and Belfast each has striven to be wholly independent of the other. There has been lamentably little co-operation between the two states and both have been equally negligent of the common interest ... Is it too much to hope that it will be followed in the near future by more tangible proofs of a better and saner spirit between Dublin and Belfast? ${ }^{132}$

In his study of the roots of the Ulster conflict, Narrow Ground, A.T.Q. Stewart writes that 'partition is not a line drawn on a map; it exists in the hearts and mind of people'. ${ }^{133}$ And unlike De Valera's 'thing in men's mind' this Ulster did exist in reality. The border was a 'very rough and ready attempt to follow the real division

131 Joseph Devlin, speech to House of Commons, 28 March 1927, Parliamentary Debates (Commons NI) series 1vol. 8 col. 438.

132 Irish Times, 23 March 1927.

${ }_{133}$ ATQ Stewart, Narrow Ground: The roots of the Ulster Conflict, 159. 
of the people'. It has been suggested the Government of Ireland Act in 1920 'simply created a more specific 'north' and 'south' as a new and sharper focus for traditional attitudes which made formal a partition which had been informally accepted'. ${ }^{134}$ Speaking in 1923 Andrews claimed:

What some persons do not evidently appreciate is that the forces which divide us here in the North from Southern Ireland are far more insuperable than the few miles of water which separate us from Great Britain geographically. We have retained intact every foot of our Six County area.... we intend to remain immovable in this connection. ${ }^{135}$

By 1925 the boundary between Northern Ireland and the rest of the island was secure and had become an international frontier. This is revealing for what it says about the story of the red route for Northern Ireland. When Northern Ireland as an entity was uncertain the clamour was great, when its status was secure, the clamour diminished. Robert Lynn claimed it was at odds with the government's ethos and opposed to the permanent interests of unionists. Many of the unionist objections to the reversal had been based on distrust of an Anglophobic south. These unionists saw an all-red route as part of consolidating a distinctive rule and strengthening partition. By contrast those who supported the reversion to the

${ }^{134}$ C. O'Halloran, Partition and the Limits of Irish Nationalism, (Dublin 1988) 5-6.

135 Frontier Sentinel, 1 September 1923. 
Holyhead route desired a united Ireland and elimination of the 'National Government and Parliament of Northern Ireland'. ${ }^{136}$ Bilig has argued that in areas of contested identity, symbols of nationhood are not mindless. The quest to establish an all-red mail route is an example of a mindful symbol of nationhood. ${ }^{137}$ Both unionists and nationalists saw it as either affirming or challenging their sense of national identity.

Underlying the unionist view was the by now palpable fact that Ulster was part of the United Kingdom and as such its mail should only pass through Great Britain to Northern Ireland. The failure to achieve an all-red route was, it was claimed by those championing a distinct Ulster geography, one step to domination by a Dublin Parliament and a nail in the coffin of Ulster's union with Britain. 'By abandoning the all-red route or postponing its establishment to the dim and distant future, the Northern government would unwittingly play the game of those whom in the past it has withstood with such admirable determination and courage'. ${ }^{138}$

\footnotetext{
136 Northern Whig, 23 March 1927

${ }^{137}$ Bilig, Banal Nationalism, 41.

138 Northern Whig 29 March 1927.
} 
Countering this view is the nationalist perspective. The decision to revert the mails to the old route was hailed as a victory by nationalists. In spite of partition nationalists continue to imagine Ireland as one unit and the quest for an all-red route was considered a 'waste of public money in a futile effort to make this Partitionist frenzy triumphant over the facts and economy'. ${ }^{139}$ The attitudes displayed by the Free State press reflect the irredentist claim on Northern Ireland, a claim based primarily on notions of territory and geography. The Irish Free State made no official comment on the all-red route but the issuing of stamps, 'products of the state and constantly present, ${ }^{\prime 140}$ which displayed a 32 county map of Ireland underlined this claim.

Craig's decision to announce the all-red route and then to abandon it so publicly three weeks later remains a puzzle. Craig's chief biographer has argued that one of his defects as leader was his failure to see policies through. ${ }^{141}$ He has been accused of being unwilling to impose his views on others often letting his own views be overruled. ${ }^{142}$ One newspaper editorial claimed that if the BCC was the main proponent of the all-red route then 'he should have been strong and shrewd enough to resist them.... He yielded and embarked on a devious course

\footnotetext{
139 Irish News, 29 March 1927.

${ }^{140}$ P. Raento and S.D. Brunn, 'Picturing a Nation: Finland on postage stamps', National Identities 10, 1, March 2008, 49-75, 49.

${ }^{141}$ Buckland, James Craig, 84 .

142 ibid, 85-6
} 
which resulted in a 'humiliating failure'. ${ }^{143}$ This incident could also be seen as an instance of the problem the nature of government in Northern Ireland; that politics seemed to be done on the outside, that is, that policies and decisions were made anywhere but in Parliament. ${ }^{144}$ It also highlights the great gap between the regional party and Westminster. It has been argued that Ulster Protestants made Stormont, not Westminster, the centre of their political life and a potential focus of allegiance $^{145}$ hence it is not surprising that Craig should make this decision despite the fact that his colleagues at Westminster were engaged in continuous negotiations over the practicalities of improving the alternative routes. On the other hand the incident could be seen as part of the changing nature of Craig's relationship with the south. He began his premiership with noble notions of conciliation with the south but by the mid-1920s he became increasingly combative and Unionism itself became more hostile and insular by the 1930 s. ${ }^{146}$

The relationship between Ulster businessmen and the Unionist party is also important here. The business community, and the BCC in particular, was a major supporter of the unionist regime. It has even been argued that without the leadership and financial resources of Ulster businessmen in the years 1880-1921,

\footnotetext{
143 Irish News, 29 March 1927.

${ }^{144}$ Buckland, Factory of Grievances, 35.

${ }^{145}$ D. Miller, Queen's Rebels, 130.

${ }^{146}$ Reid, 'Protestant challenges to the 'Protestant State,' 424. See all M.J. Kennedy,
} 
Ulster Unionism could not have assumed the significance it did in the twentieth century. ${ }^{147}$ The way the mails were handled and the eventual volte-face which Craig made over the all-red route was, for the most part, due to the influence of the business community and illustrate, up to a point, the limits of Ulster Unionism in projecting their political goals. Furthermore as well as providing an example of the 'short term 'survivalist' mentality of Ulster Unionism'148, and its provincial mentalité149, it also serves to underline the fact that there existed tensions within unionism and that the nature of UUP hegemony, as has been argued elsewhere, was incomplete ${ }^{150}$. Indeed part of the reason for the eventual outcome on the mail issue is the divided nature of Ulster unionist opinion which must be taken into account in understanding the evolution of unionism in the 1920s.

During the debate which followed the decision to revert the mails the Belfast News-Letter argued there was 'never any political significance in our government's decision'151. But in Northern Ireland, particularly at such a stage in its development, such events were always given political significance. To a large extent the significance of the quest for an all-red route lies in the reading of it, and

\footnotetext{
${ }^{147}$ Ollerenshaw, 'Businessmen and the Development of Ulster Unionism,' 58-9.

${ }^{148}$ Walker, A History of the Ulster Unionist Party, 63

${ }^{149}$ McBride, 'Ulster and the British Problem,' 7.

${ }^{150}$ Reid, 'Protestant challenges to the 'Protestant State' 444.

151 Belfast News-Letter, 29 March 1927.
} 
how it came to represent different aspirations for the two communities in Northern Ireland and the role the postal system could play in those aspirations. 